\title{
Entre pesca e turismo balnear: Alternativos engajamentos dos moradores de Marudá (Amazônia Atlântica) ao trabalho
}

\section{Between fishery and beach tourism: Alternatives of labor allocation in Marudá (Atlantic Amazon)}

\author{
Diego Corrêa Furtado
}

\begin{abstract}
RESUMO: Visando contribuir para a relativização da ideia que prognostica a aculturação como inevitável destino de populações interioranas receptoras de fluxos turísticos, o texto se reporta ao caso da localidade litorânea de Marudá (Marapanim, Pará) e investiga como o intercurso entre moradores e turistas influencia os estilos de vida ali atualizados. Mediante observação participante e entrevistas, descreve o engajamento a concorrentes esferas de trabalho no local: pesca, mariscagem, extrativismo vegetal, por um lado; prestação de serviços a turistas, por outro. Reconhece, também, que o turismo de segunda residência, modalidade identificada em Marudá, se distingue de outras modalidades por implicar participação mais ativa dos atores locais na definição dos processos de mudança social. Conclui, finalmente, que a vida balnear não constitui fator de desarticulação dos estilos de vida locais, mas apenas alternativo conjunto de recursos, a que os marudaenses podem se vincular diversamente na busca pela subsistência.
\end{abstract}

PALAVRAS CHAVE: Assimilação; Modernização; Mudança Social; Povos Tradicionais.

\begin{abstract}
Intending to support the relativization of the idea that predicts acculturation as the inevitable fate of traditional peoples in continuous contact with touristic flows, this text analyzes the case of the coastal locality of Marudá (Marapanim, Pará) and investigates how the interaction between residents and tourists influences local lifestyles. Through participant observation and interviews, it describes the patterns of labor allocation in two alternative spheres: fishing, shellfish collecting, plant extractivism, on the one hand; provision of services to tourists, on the other. The study also recognizes that second-home tourism, the modality identified in Marudá, differs from other modalities because it implies a more active role of local actors in the definition of social change process. Thus, the paper concludes that beach tourism does not entail the collapse of local lifestyles; it merely figures as an alternative set of resources, of which the Marudaenses can take advantage to fulfill their needs.
\end{abstract}

KEYWORDS: Assimilation; Modernization; Social Change; Traditional People. 


\section{Introdução}

A constituição do turismo como ramo especializado de estudos acadêmicos guarda semelhanças com as origens da Antropologia, uma das áreas precursoras no estudo dos fenômenos turísticos e ainda relevante em sua análise contemporânea (BARRETTO, 2003). Remontando ao contexto da expansão marítima europeia, os inaugurais esforços de catalogação dos traços culturais das sociedades descobertas pelos navegadores - ditas "selvagens" ou "primitivas" - decorreram da ideia de que o contato levaria à perda da cultura própria dessas sociedades e à adoção da cultura dos colonizadores (CUCHE, 1999; NEVES, 1995; NEVES, 2017).

Embora contestadas pela tradição antropológica subsequente, entre as décadas de 1950 e 1970 (FELDMAN-BIANCO, 1987), os esquemas interpretativos calcados em tais noções de assimilação cultural ou difusão cultural continuaram a inspirar outros campos de investigação tangencialmente referidos à temática social. Este é o caso dos estudos do turismo, que, tomando corpo a partir da década de 1970, tenderam a prescrever que as mudanças sociais nas localidades receptoras de fluxos turísticos levariam à aculturação dos povos nativos e sua homogeneização cultural à sociedade globalizada abrangente (SANTOS; BARRETTO, 2006). Reiterava-se, assim, uma concepção já criticada de cultura, que, negando seu caráter dinâmico, a entendia como conjunto de traços permanentes, demarcatórios de um idealizado isolamento geográfico e social dos povos nativos (CUNHA, 2007).

O entendimento do fenômeno turístico com base na citada perspectiva se deveu à significativa atenção concedida a casos em que o turismo alcançava maior projeção comercial, até em nível internacional, gerando constrições aos modos de vida dos povos nativos (p. ex., CAROSO; RODRIGUES, 1998; GASCÓN; MILANO, 2018; NETTO; MIRALDI, 2017; OLIVEIRA, 2005). Em outros casos, atribuiu-se ao turismo a causa de mudanças que, de fato, se iniciaram a partir de processos anteriores de indução de contato entre distintas sociedades, sobretudo aqueles ligados ao colonialismo (SANTOS; BARRETTO, 2006).

Contudo, a exemplo do que ocorreu com a Antropologia, os estudiosos do fenômeno turístico passaram, gradativamente, a desenvolver a concepção de que as populações anfitriãs não são meros receptáculos de influências externas. A interação com os turistas se configuraria, assim, não como imposição, mas negociação em torno do processo de mudança (BARRETTO, 2003). Reconhecer as influências recíprocas entre os membros de distintas sociedades ou segmentos sociais como eixo de análise de qualquer situação de contato não significa, no entanto, advogar que tais interações sejam pacíficas, nem que haja simetria na distribuição de poder entre os agentes em intercurso (CUCHE, 1999). Significa que o registro e a interpretação da mudança devem se pautar por perspectiva contextual, enfocando as especificidades de cada caso particular (PRADO, 2003; LOPES JÚNIOR, 2015).

O termo turismo figura, afinal, apenas como rótulo genérico de distintas práticas de visitação temporária recreacional, diversamente 
manifestas no plano empírico (BARRETTO, 2003; PRADO, 2003). E, dentre suas diversas maneiras de objetivação, o turismo de segunda residência se destaca como modalidade favorável à percepção da capacidade de agência dos atores locais e do caráter negociado da mudança social desencadeada pelo estabelecimento de fluxos turísticos.

O turismo de segunda residência se caracteriza pela compra ou construção de imóveis residenciais em localidades litorâneas ou rurais, por pessoas desejosas de se retirar do cotidiano urbano durante finais de semana e períodos de férias. Tais imóveis constituem domicílios secundários das famílias urbanas e sua distância em relação aos domicílios citadinos é influenciada pelos custos monetários e de tempo associados à realização do movimento pendular de visitação periódica, o que condiz com circuitos turísticos predominantemente regionais (ASSIS, 2003).

De Assis (2001) e Adrião (2006) a Martins e Molina (2008), cunhou-se o entendimento de que, embora promova mudanças diversas, o turismo de segunda residência não implica destruição dos estilos de vida dos moradores das áreas receptoras. Como a presença de turistas responde a uma sazonalidade específica (férias versus baixa temporada), a mudança vivida pelos moradores dos polos de turismo é interpretada não como fatídica e plena conversão a estilos de vida da sociedade urbana, mas como configuração de híbridos estilos de vida, tributários tanto da anterioridade temporal quanto do periódico intercurso estabelecido com os veranistas. Tal percepção é consistente, inclusive, com observações realizadas no contexto do litoral amazônico (p. ex., BARBOSA; CAMPOS, 2017; CAMPOS; NASCIMENTO; MENDONÇA, 2017; SILVA et al., 2016), em que se passa a indicar o turismo de base comunitária como alternativa de valorização do conhecimento tradicional remanescente das populações residentes nas localidades turísticas.

O nexo entre sazonalidade turística e configuração de híbridos estilos de vida passou, assim, da condição de hipótese implícita - e ainda relativamente ofuscada pela noção de conversão de estilos de vida -, em Assis (2001) e Adrião (2006), até a de proposição explícita, em Martins e Molina (2008). A demonstração empírica deste nexo, porém, é tarefa ainda pendente. Por isso, o presente artigo se reporta ao caso das práticas turísticas objetivadas na localidade litorânea de Marudá (Marapanim-PA) para ilustrar, via análise de relações circunscritas à esfera do trabalho, o modo como os moradores do lugar atualizam estilos de vida híbridos, conformes ao sazonal intercurso estabelecido com seus vizinhos temporários, os turistas citadinos.

Além de corroborar uma determinada via interpretativa com dados empíricos especificamente produzidos em torno da categoria "cotidiano", o texto também sugere que o recurso à categoria "interação" como aspecto prioritário de análise nos estudos do turismo poderia figurar como salvaguarda ante interpretações desgastadas e geralmente infrutíferas, ligadas às noções de aculturação e assimilação cultural. Como se pretende demonstrar, tais interpretações, produzidas em contextos ambíguos de mudanças e permanências, tendem a recair em determinismos e fatalismos, 
tanto mais quanto menos atentas às efetivas interações estabelecidas entre os atores sociais nos cenários de objetivação do turismo.

\section{Contexto empírico e método de investigação}

Marudá é um distrito do município de Marapanim, no nordeste do Pará. Dista $160 \mathrm{~km}$ da capital, Belém, na estreita faixa do litoral oceânico amazônico (Figura 1).

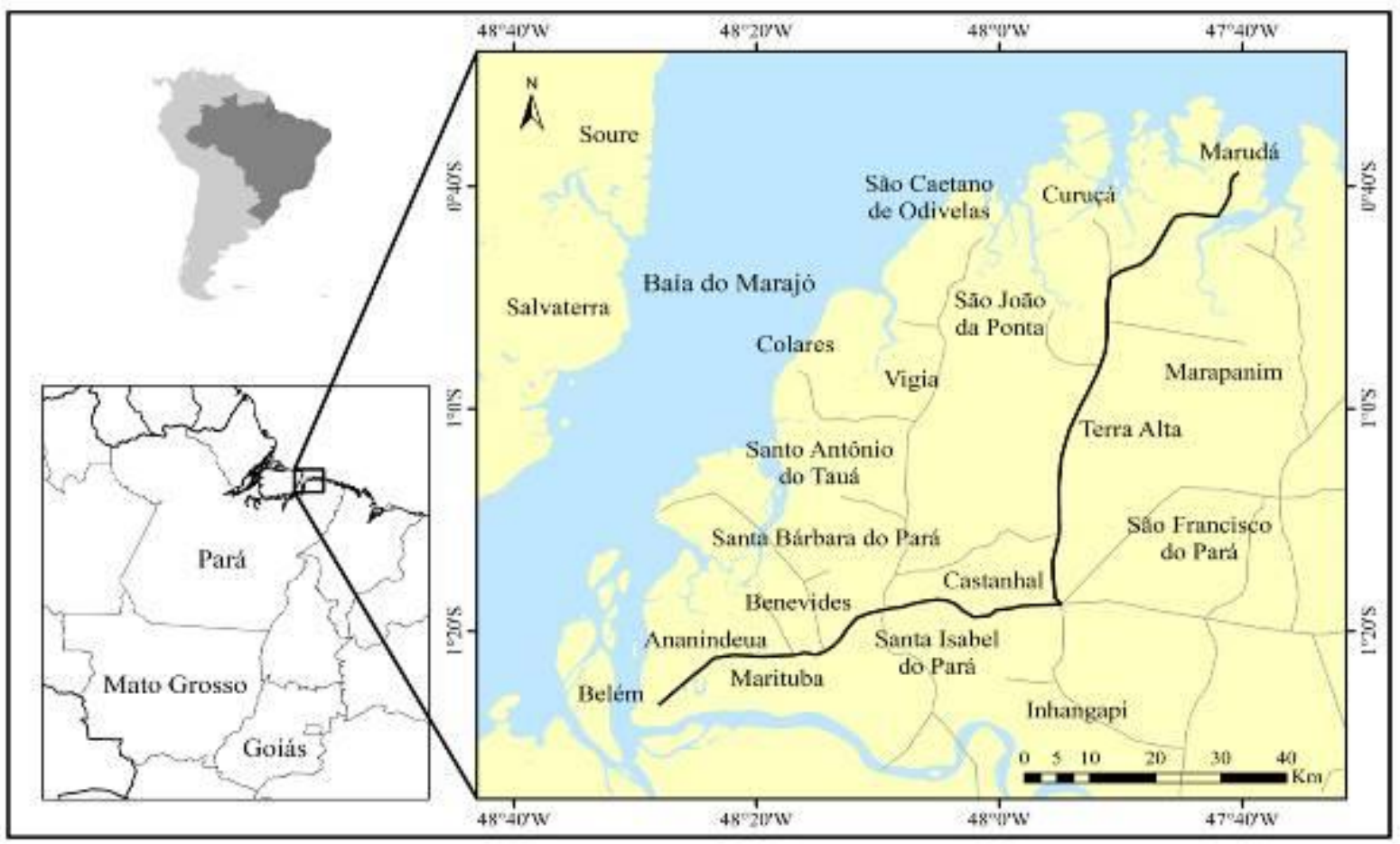

Figura 1: Área de estudo e acesso a partir de Belém. Fonte: Naraiana L. Benone (2018).

Figure 1: Study area and access from Belém. Source: Naraiana L. Benone (2018).

Nas décadas de 1930 e 1950, melhorias na infraestrutura rodoviária facilitaram o escoamento do pescado que ali abundava e a localidade se converteu em polo pesqueiro (FURTADO, 1978). Visando superar condições econômicas adversas, moradores de outras localidades - inclusive de municípios pouco beneficiados pela ampliação da malha viária - afluíram a Marudá, onde passaram a atualizar a pesca em modalidade exclusiva, contrastando com a produção polivalente que outrora realizavam (FURTADO, 1978; POTIGUAR JÚNIOR, 2001).

Nos anos 1980, porém, cresceu o interesse pelas praias do local, cujo aspecto rústico oportunizava experiência alternativa de lazer balnear. No final dos anos 1990, já se tinha Marudá como polo balnear, atraindo levas de visitantes a cada "veraneio" (termo local, sem conotação climática, referente aos períodos de férias escolares, em julho, dezembro e janeiro). Enquanto os moradores persistiam ligados à pesca, o turismo de caravana ou piquenique se convertia, de modo gradual, em turismo de segunda residência (cf. ASSIS, 2001, quanto à terminologia), originando-se 0 segmento de moradores sazonais (FURTADO et al., 2006). 
Visando estimular o turismo, dotou-se a paisagem do distrito de aspecto relativamente urbanizado, com asfaltamento de algumas ruas. Limítrofes à costa oceânica, Sossego e Alegre (Figura 2) foram os principais bairros escolhidos pelos moradores sazonais para sediar suas residências algumas casas de alto padrão; a maioria, de padrão médio. Tendo vendido suas propriedades para veranistas, significativa parcela da população original desses bairros se deslocou para pontos mais distantes da orla atlântica (FURTADO et al., 2006), formando novas e precárias aglomerações populacionais, localmente chamadas de "invasões". Resulta, disso, o padrão observado durante o trabalho de campo, de esvaziamento dos dois bairros citados fora do período de veraneio (Figuras 3 e 4), quando as casas ali existentes, em sua maioria, permanecem fechadas.

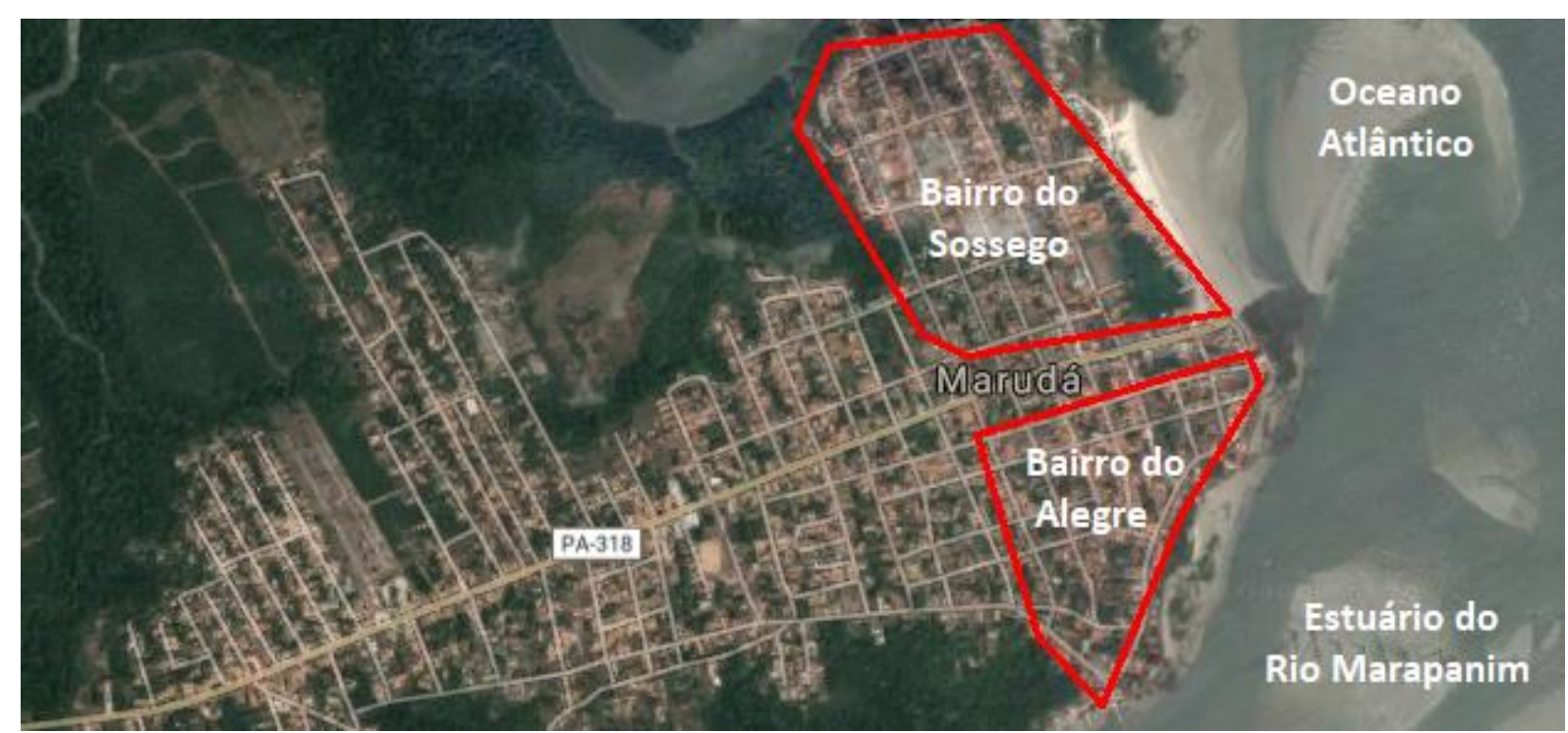

Figura 2: Imagem de satélite dos bairros costeiros de Marudá. Fonte: Google Maps (2018). Figure 2: Satellite image of Marudá coastal neighborhoods. Source: Google Maps (2018).

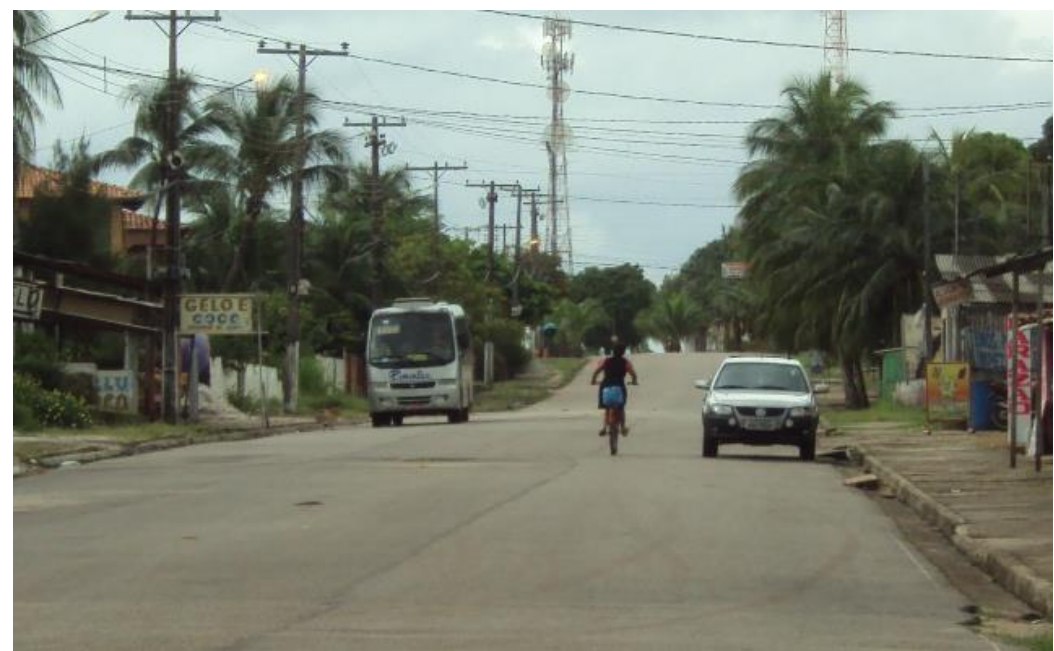

Figura 3: Aspecto esvaziado da rua principal de Marudá na baixa estação.

Fonte: pesquisa de campo (2017).

Figure 3: Empty aspect of the main street of Marudá during touristic low season. Source: field research (2017). 


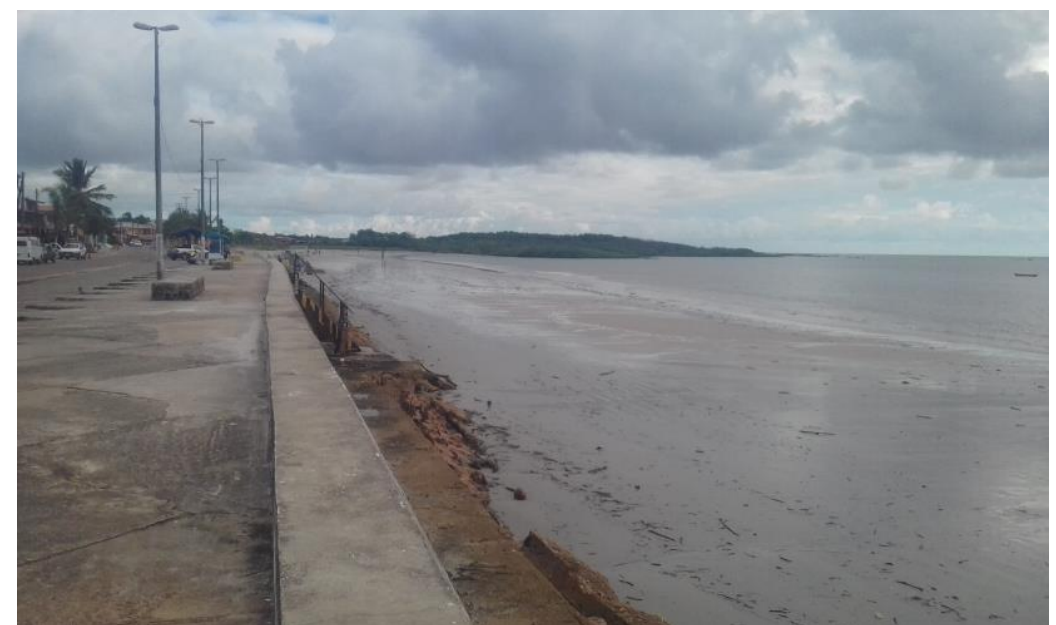

Figura 4: Aspecto esvaziado da orla e da praia de Marudá na baixa estação. Fonte: pesquisa de campo (2017).

Figure 4: Empty aspect of the beachfront and Marudá beach during touristic low season.

Source: field research (2017).

Ao tempo em que os moradores permanentes do local passaram a se engajar à vida balnear - como caseiros de residências secundárias, pedreiros, vendedores em pontos de comércio -, a atividade pesqueira entrava em declínio (COELHO-FERREIRA, 2009). A literatura registra, porém, as seguintes causas para tal declínio: relações desfavoráveis com intermediários da cadeia de comercialização do pescado; ingresso de novos pescadores e crescente pressão sobre o estoque pesqueiro, conduzindo à escassez do recurso; contradição entre sazonalidade das espécies visadas de peixe e prática da pesca como atividade exclusiva, dificultando a satisfação das necessidades ao longo de todo o ciclo anual (FURTADO, 1978; NASCIMENTO, 2006; POTIGUAR JÚNIOR, 2001). A relação entre ascensão do turismo e declínio da pesca não seria, portanto, de causa e efeito. Ainda assim, os dois processos estariam ligados, devido à emergente possibilidade de alternância da vinculação dos moradores permanentes a distintos universos de práticas sociais, a vida haliêutica e a balnear, instaurada pelo sazonal padrão de visitação turística.

O estudo da articulação entre esses dois universos de práticas sociais, que muito se socorre da análise da interação entre moradores permanentes e sazonais (estes, por definição, turistas), decorre de pesquisa empírica, realizada nos bairros do Sossego e Alegre, durante diversas viagens ocorridas entre junho e novembro de 2017 - ainda que o autor acumule experiências desde 2011 no local. Além da observação direta do cotidiano dos moradores desses bairros e do estabelecimento de contatos fortuitos e conversas informais com membros dos distintos segmentos populacionais enfocados, realizaram-se entrevistas semiestruturadas com 20 moradores permanentes, residentes em diferentes casas da localidade. 


\section{Ocupações dos moradores do Sossego e do Alegre}

\section{$A$ vizinhança marudaense e a função de caseiro}

Os moradores permanentes do Sossego e Alegre se arrogam como marudaenses, seja por nascimento ou pelo tempo de moradia e senso de pertença ao lugar. Apesar de o solo estar primordialmente devotado ao uso residencial, a população efetivamente residente é ínfima. A maior parte das casas é ocupada apenas episodicamente, no veraneio e em finais de semana e feriados - mormente na situação referida como feriado prolongado, quando feriado nacional, estadual ou do município de Belém (onde grande parte dos moradores sazonais de fato reside) incide em sexta ou segunda-feira, emendando-se ao final de semana.

No veraneio, a saturação demográfica impõe a intensificação de interações face a face, contudo majoritariamente anônimas, devido à preponderância de encontros entre completos estranhos. Na baixa temporada, ao contrário, embora pareça mínima a probabilidade de encontros face a face, eles ainda são frequentes; agora, porém, não devido à saturação, mas ao investimento na organização de vizinhanças. Tais vizinhanças pouco refletem o aspecto espacial suscitado pela palavra, afinal, as casas com habitantes permanentes estão, não raro, separadas entre si por três, quatro ou mais casas vazias. Elas funcionam, mais precisamente, como redes que vinculam grupos de moradores permanentes mediante atualização de relações de compadrio, reciprocidade e valorização da história compartilhada.

São alguns desses moradores permanentes que atuam como caseiros das propriedades de moradores sazonais. Aqueles dizem ver estes, seus vizinhos temporários, como vizinhos normais, "quase como da família" (dona L., 63 anos), pois, embora não seja contínuo o convívio, há uma recorrência de contatos ao longo dos anos. Por isso, os moradores sazonais não se equiparam aos visitantes ocasionais, que, despojados de vizinhança, são os verdadeiros anônimos. É, então, um certo sentido de comunidade que preside os vínculos entre caseiro e patrão, e é dentro dessas coordenadas que o patrão encontra condições de reocupar, episodicamente, sua posição nas redes de vizinhança, liberando-se, por algum tempo, das posições ocupadas nos sistemas de hierarquização social de que participa no cotidiano urbano (cf. a noção de communitas em Turner, 1975). Assim, quando, por alguma eventualidade, finda a vinculação de prestação de serviços de um caseiro em uma casa de veraneio, não são raros os casos em que, por anos sucessivos, o proprietário da casa - morador sazonal do balneário - e o ex-caseiro - morador permanente -, estando ainda temporariamente avizinhados, realizam e retribuem visitas entre si, retomando lembranças e atualizando o vínculo social.

A função de caseiro abarca, minimamente, as tarefas de vigiar a casa do vizinho ausente (vizinho-contratante), de acender, ao fim da tarde, as lâmpadas do pátio frontal dessa residência e de apagá-las ao amanhecer. Além disso, pode também abranger uma série de outras tarefas, ligadas à limpeza e à manutenção física e estética da residência de veraneio. A faxina do interior da casa é realizada preferencialmente por mulheres e a roçagem 
(capina, "limpeza") e a jardinagem do terreno e do entorno da propriedade são realizadas por homens. A roçagem pode ser feita com uso de terçado ou fogo. A jardinagem, por sua vez, engloba a remoção de ervas daninhas, a poda de árvores e arbustos e a rega de folhas, de plantas tenras e do gramado. Esse conjunto de tarefas, em alguns casos, é executado por uma só pessoa, porém é mais comum, em Marudá, que o caseiro se constitua como figura coletiva, o que corresponde à distribuição das diversas atribuições listadas entre os diferentes membros de uma mesma família de moradores permanentes.

A periodicidade das tarefas de manutenção da casa de veraneio varia conforme: (1) os termos do acordo entre caseiro e vizinho-contratante; (2) o montante do pagamento mensal (e seu potencial de remuneração do esforço dispendido); (3) a frequência de utilização da casa de praia; e (4) o grau de estima pessoal auferido pelo contratante na vizinhança local. Certos serviços, como a rega de plantas, nas épocas mais quentes e menos chuvosas do ano, são realizados quase todos os dias. A faxina e a roçagem, por outro lado, tendem a ocorrer a cada um ou dois meses, ou apenas às vésperas do veraneio ou de feriados, quando o proprietário da residência avisa ao caseiro acerca da iminência de sua chegada.

A função de caseiro é remunerada mediante variados valores e modalidades. Quando o acordo prevê pagamento mensal, o valor varia entre $R \$ 100$ e $R \$ 150$. O dinheiro pode ser depositado em conta bancária do caseiro ou, mais frequentemente, entregue em mãos, na oportunidade de algum final de semana em que o proprietário da casa de veraneio visite 0 litoral. Como as ocasiões de visita são imprevisíveis e, às vezes, espaçadas entre si por vários meses, a segunda modalidade de pagamento tende a gerar atrasos e alguma insatisfação no caseiro, embora os débitos retroativos sejam devidamente quitados pelo vizinho-contratante.

Há, porém, modalidade não monetária de retribuição pelo desempenho da função de caseiro, limitada à tarefa de "reparar a casa". Mantendo-se alerta a movimentos estranhos em torno da residência do vizinho ausente e seguindo a rotina de acender e apagar as luzes do pátio frontal, o caseiro aufere, como retribuição para sua família, a prioridade de contratação, pelo morador sazonal, para realizar as faxinas que antecedem cada visita da família citadina a Marudá. Assim, às vésperas do veraneio e de feriados prolongados, a família local responsável pela vigilância da casa de praia obtém a oportunidade de ser remunerada em $R \$ 200$ a $R \$ 300$ pelo serviço de recepção de seus vizinhos temporários.

De todo modo, a avaliação formulada pelo morador permanente quanto à justiça da remuneração concedida pelo vizinho sazonal parece refletir menos o valor da quantia em si que a percepção de compatibilidade entre tal valor e o poder econômico que o contratante aparenta possuir. Assim, uma mesma quantia pode ser valorada como pagamento justo ou como "mixaria, quando dá para ver que a pessoa tem como dar mais, mas prefere dar só um pouquinho" (dona M., 79 anos). A boa ou má reputação que os moradores sazonais assim auferem potencialmente influencia sua capacidade de integração às redes da vizinhança marudaense. 
É comum a construção de duradouros vínculos entre caseiros e vizinhos-contratantes, registrando-se casos em que as relações de prestação de serviços se estendem por até 25 anos. Porém, tais relações não são essencialmente estáveis nem uniformes ao longo do tempo. Caseiros podem abandonar o posto, inclusive indicando substitutos, de sua parentela, ao contratante. Por outro lado, moradores sazonais podem se desgastar perante os custos e dissabores de manter uma casa de praia, vendendo-a e, possivelmente, indicando seu caseiro de confiança para o comprador. Além disso, essas relações não são exclusivas, sendo comum que determinado caseiro preste serviços a dois, três ou vários de seus vizinhos sazonais.

Contrastando com a prática usual, há moradores sazonais que não contratam serviços de caseiros, opção que se reflete na existência de propriedades com aparência de desmazelo e abandono (Figura 5), preferencialmente visadas por ações de invasão e furtos. Há, por outro lado, casos de moradores permanentes que não atuam como caseiros, mas prestam serviços pontuais aos moradores temporários, como limpeza de caixas d'água e piscinas, obras de alvenaria, pintura de casa, faxina e instalação de antenas de televisão.

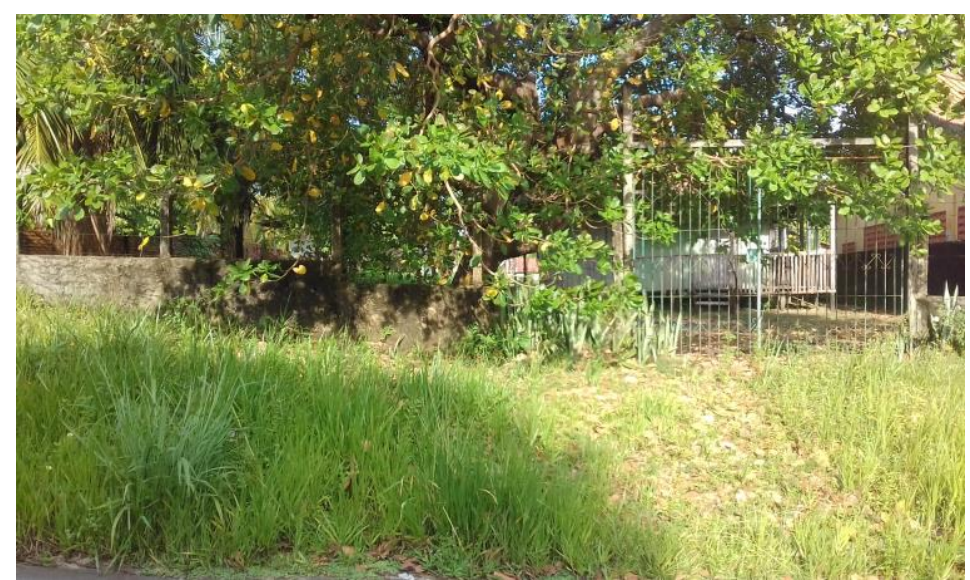

Figura 5: Aspecto de abandono de uma casa de veraneio não atendida por caseiro.

Fonte: pesquisa de campo (2017).

Figure 5: Aspect of abandonment of a beach house not attended by a housekeeper. Source: field research (2017).

Em situações de estadia prolongada dos moradores sazonais nas casas de praia, como ocorre em julho, alguns caseiros passam a desempenhar a função de empregados domésticos, intensificando as rotinas de prestação de serviços e aumentando a remuneração auferida.

Em julho, aliás, as oportunidades são múltiplas. Estimulados pelo intenso fluxo de veranistas - sobretudo daqueles desprovidos de casa de praia -, é comum que moradores permanentes aluguem suas casas para famílias ou grupos de amigos oriundos de Belém. Durante a estadia dos visitantes, que dura de 15 a 30 dias, a família nativa se muda para aposentos menores e precários, nos fundos de sua propriedade, construídos precisamente para permitir a liberação da casa principal no veraneio. Algumas famílias da cidade até mesmo buscam, por anos seguidos, as 
mesmas casas de moradores permanentes, para reocupá-las nesta época. Trata-se de um curioso caso de habitação sazonal sem segunda residência e de lealdade entre vizinhos temporários sem a constituição da figura do caseiro.

Na baixa temporada, ao contrário, as oportunidades se escasseiam, privilegiando as funções de vigilância, manutenção física de propriedades e construção civil. Neste período, que dura a maior parte do ano, os caseiros, mesmo quando envolvidos em acordos que preveem cuidados frequentes às casas dos vizinhos-contratantes, ainda dispõem de considerável parcela de tempo para investir em ocupações adicionais.

\section{Ocupação de pedreiro}

São frequentes, em Marudá, casos de homens que se apresentam como pedreiros profissionais. Embora tenham um passado ligado ao exercício da pesca em modalidade intensiva, tenderam a privilegiar o vínculo ao ramo da construção civil a partir do momento em que se consolidou a conformação de um turismo de segunda residência na localidade. Afinal, o deslocamento de famílias nativas para áreas periféricas do lugar e a consequente ocupação de terrenos centrais por famílias de veranistas ensejaram a adequação do casario ao perfil socioeconômico de uma classe média urbana acostumada a um nível de conforto e a padrões estéticos que destoam dos padrões do antigo povoamento.

Durante as décadas de 1990 e 2000, diversos motivos concorreram para que famílias nativas de Marudá também promovessem a adequação de suas casas ao cenário turístico constituído naqueles bairros costeiros. A influência estética oriunda das casas dos vizinhos sazonais e a diversificação das fontes de renda monetária em decorrência dos postos de ocupação ligados ao turismo foram dois desses fatores. Adicionalmente, porém, a constituição de um corpo profissional estável de pedreiros e a abertura de lojas especializadas em materiais de construção em Marudá favoreceram esse processo na medida em que, concentrando na própria localidade os recursos necessários à condução de obras civis, tornaram a edificação de casas de alvenaria um empreendimento menos dispendioso. Assim, as casas de madeira ou taipa se tornaram cada vez mais raras nos bairros costeiros de Marudá.

Com a consolidação de um cenário turístico ameno, a demanda por serviços de construção civil tem se tornado escassa. Ainda há, decerto, casas sendo construídas, como também ainda ocorrem deslocamentos de moradores permanentes para regiões periféricas, visando à cessão de terrenos centrais para incorporação à dinâmica balnear. Tais processos, entretanto, se desdobram em ritmo menos intenso que nos recortes temporais precedentes, pois o ingresso de novos moradores sazonais nas vizinhanças marudaenses passa a acontecer por via da compra de casas de veraneio de segunda mão, adquiridas de proprietários que, por diversos motivos, declinam da condição de moradores sazonais do balneário.

Assim, a tônica do ofício de pedreiro se direciona a pequenas obras ou reformas, para manutenção das residências e dos pontos comerciais. 
Porém, a autodefinição como pedreiros ainda se expressa de modo bastante explícito entre marudaenses do sexo masculino. Isso se deve, possivelmente, em primeiro lugar, à estabilidade do ramo da construção civil durante a fase de requalificação da paisagem marudaense. Uma ou duas gerações de jovens, afinal, foram socializadas no mundo do trabalho tendo por base esse ofício, organizando-se aos moldes de corporações familiares. Em segundo lugar, a identificação reivindicada ao ofício de pedreiro pode também decorrer de seu reconhecimento como ocupação demandante de diferenciadas qualidades físicas e, portanto, restrita à esfera de atuação masculina. Seria, por isso, dentre o conjunto de ocupações constituídas na esteira dos fluxos de visitação turística, aquela inspiradora de um simbolismo análogo aos sentidos outrora atribuídos exclusivamente à pesca como domínio de referência da masculinidade no local.

\section{Funções de atendimento ao comércio}

Ocupação que também emerge com a constituição de Marudá como polo balnear é o atendimento ao público em pontos comerciais: hotéis, pousadas, bares, lanchonetes, barracas de lanches, mercearias, padarias, farmácias, lojas de roupas, lojas de materiais de construção, supermercados. Na baixa temporada, tais estabelecimentos mantêm um corpo relativamente estável - e reduzido - de funcionários, que engloba, primordialmente, membros da família do proprietário do negócio. Nos dias de semana, alguns desses pontos registram movimento ínfimo, liberando os familiares-funcionários para ocupar seu tempo em outras atividades. Porém, nos finais de semana - especialmente em feriados prolongados -, todo 0 corpo fixo de funcionários é chamado a reocupar suas funções no comércio. Quando o fluxo de visitantes ultrapassa as expectativas, convoca-se mãode-obra adicional para prestação de serviço em caráter episódico ("bico"). A mão-de-obra adicional se constitui por moradores permanentes de Marudá ou localidades próximas, como Camará, Bacuriteua, Crispim, e que não possuem, necessariamente, parentesco com o proprietário do negócio.

Durante o veraneio, é ainda mais acentuada a contratação de bicos, visando atender o intenso fluxo de visitantes. Contudo, não é correto afirmar que a totalidade - ou mesmo a maioria - da população permanente de Marudá efetivamente se ocupe no comércio durante a alta estação, ainda que seja comum que, em uma família de moradores permanentes, ao menos um de seus membros disponha de tempo para fazer bicos e até compor o corpo fixo de algum negócio. Mesmo as pessoas consistentemente vinculadas ao atendimento no comércio, aliás, ainda dispõem de arbítrio sobre significativa parcela de seu tempo para engajamento em atividades outras, pois o vínculo de trabalho nesses pontos se atualiza mediante características de temporariedade, descontinuidade e informalidade. A constituição do trabalhador neste cenário, afinal, decorre, em regra, de admissão via acordo oral, respaldado no valor da palavra. A impossibilidade de usufruto de direitos trabalhistas, assim, é compensada pela relativa mobilidade preservada pelo funcionário, na medida em que não se encontra atado a rígidas jornadas de trabalho. 
Casos de maior rigidez no cumprimento de jornadas de trabalho existem, embora pouco frequentes. Os funcionários de uma farmácia e de um mercado localizados na via principal - que conduz à orla marítima de Marudá e separa os bairros do Sossego e Alegre -, por exemplo, cumprem jornada de trabalho similar à de trabalhadores urbanos formais. Outros mercados e lojas de construção no distrito adotam a mesma rotina, que também se aplica aos marudaenses que trabalham nos diversos pontos comerciais da sede urbana de Marapanim.

\section{Extrativismo animal: ofício de pescador}

A pesca - com uso de rede ou de armadilhas fixas de estacas de madeira (curral) - foi a atividade mais visada pelos inaugurais estudos acadêmicos enfocando Marudá. Valorizada como domínio privilegiado, foi tomada para qualificar a totalidade da vida social e econômica do lugar, frequentemente descrito como vila pesqueira, ou polo pesqueiro. No entanto, embora ainda haja moradores permanentes que pratiquem a pesca de modo exclusivo (BORCEM et al., 2011), reatualizando padrões ocupacionais que tiveram apogeu nas décadas de 1970 e 1980 (FURTADO, 1978; POTIGUAR JÚNIOR, 2001), é notável que a atividade perdeu a centralidade de que antes gozava, passando a concorrer com formas alternativas de engajamento produtivo.

A sazonalidade da pesca, as flutuações do preço do pescado e a incompatibilidade entre o esforço dispendido e os ganhos auferidos nas negociações com os intermediários levaram à percepção, pelos marudaenses, de que a atividade pesqueira, em sua modalidade intensiva, estaria ligada a um quadro de privações.

Contemporaneamente, os moradores permanecem ligados à atividade pesqueira (Figuras 6 e 7), mas, em sua maioria, não mais a praticam de modo exclusivo, nem mesmo prioritário em relação às emergentes ocupações, em especial às vésperas e durante o veraneio, quando se privilegia o intercurso com os turistas.

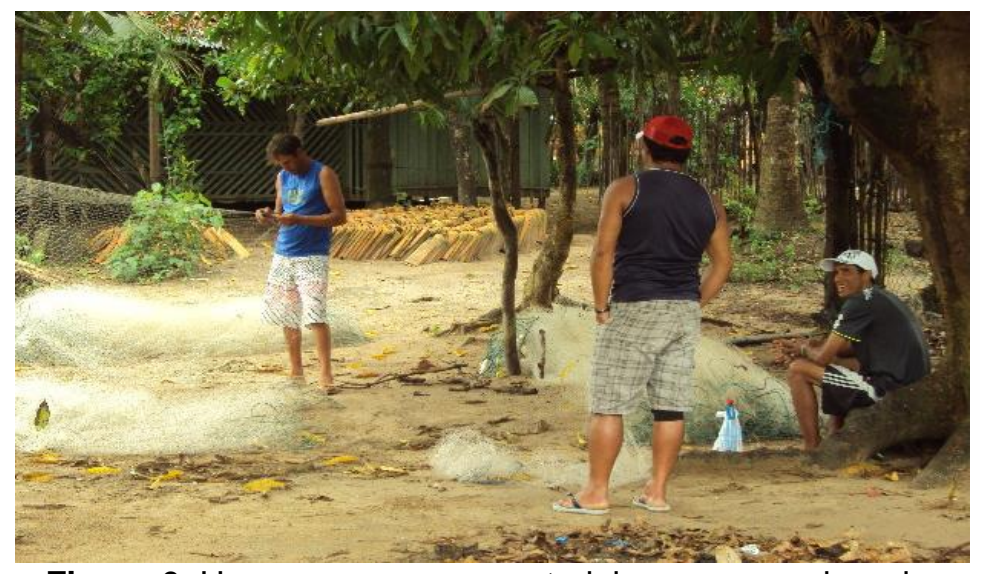

Figura 6: Homens preparam material para pesca de rede.

Fonte: pesquisa de campo (2017).

Figure 6: Men prepare equipment for net fishing. Source: field research (2017). 


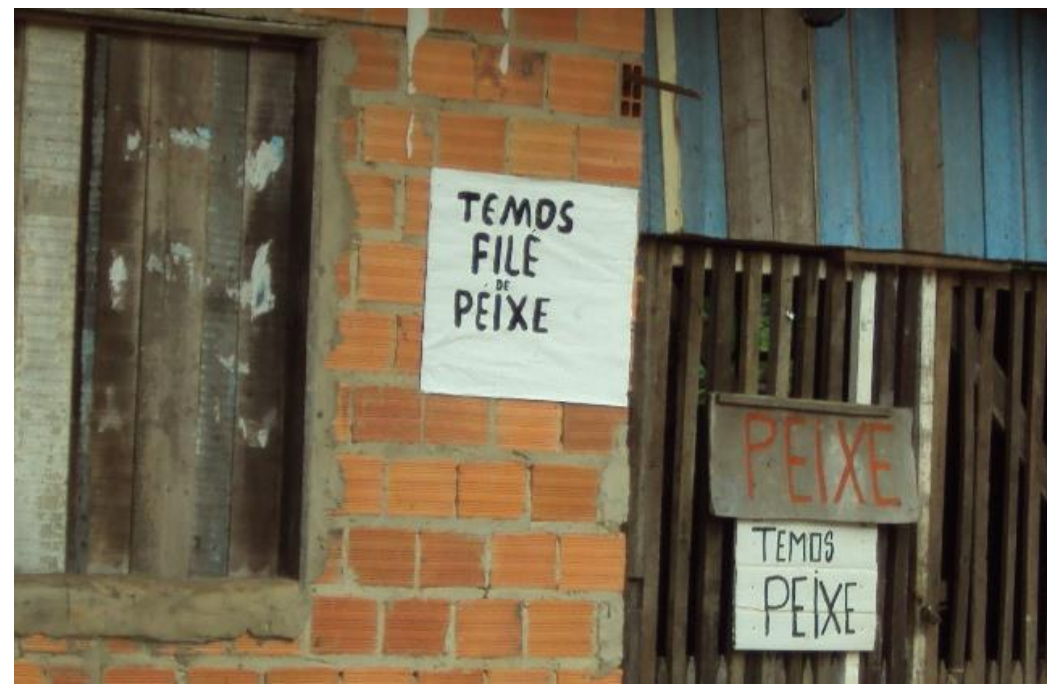

Figura 7: Anúncio de venda de pescado em casa de Marudá.

Fonte: pesquisa de campo (2017).

Figure 7: Fish sale advertisement in a house of Marudá. Source: field research (2017).

A pesca de curral é favorecida em detrimento da pesca de rede, por não exigir deslocamentos para alto-mar e consequente afastamento das ocupações paralelas, em terra. Para vários moradores, a pesca assume caráter de salvaguarda, restringindo-se a momentos em que as oportunidades de prestação de serviços a veranistas se tornam escassas: "quando não dá pra tirar no seco, tem que ir para o molhado; aí, quando aparece um trabalho, volta para a terra" (dona l., 65 anos).

Apesar de ser deslocada a planos secundários do cotidiano e de perder centralidade na formação da renda monetária de crescente parcela dos moradores de Marudá, a pesca continua, ao menos, a prover itens para autoconsumo das famílias da localidade, e permite que a satisfação alimentar não dependa exclusivamente do recurso pecuniário. Em um primeiro plano, a pesca viabiliza suprimento de proteína animal ao grupo doméstico imediato do indivíduo que a pratica. Em um segundo plano, abastece o grupo familiar mais amplo, ou família extensa, suprindo as unidades residenciais de irmãos, tios, pais e filhos do pescador. Curioso caso, inventariado a partir de interlocução com a dona L., 59 anos, diz respeito a seu esposo: pescador profissional na juventude, passou a atuar preponderantemente como pedreiro em meados da década de 1990. Ocasionalmente, porém, participa de incursões de pesca para abastecimento próprio, como também para remessas a seus familiares residentes em Belém.

Assim, a pesca preserva relevância econômica, como fonte não exclusiva de formação da renda monetária familiar ou, minimamente, como fonte de produtos para o autoconsumo doméstico. Nem sempre, afinal, sobejam oportunidades de prestação de serviços a veranistas, e, mesmo quando surgem, não são equitativamente acessíveis a todos os moradores permanentes.

Para além da importância econômica, a pesca permanece sendo valorizada, pelos marudaenses, como domínio de atuação revestido de 
significações sociais, o que também justifica sua contínua reincorporação ao cotidiano desses moradores, mesmo quando a produção dela decorrente já não representa substancial vantagem monetária. Desse modo, a pesca de rede em alto-mar, outrora descrita como fatigante e arriscada, passa a ser vista, por parcela de seus praticantes - sobretudo aqueles que galgaram posições relativamente estáveis nas redes de prestação de serviços a vizinhos sazonais -, como forma lúdica de se dispor do tempo. O que antes era dever se traveste em aventura, expressão de masculinidade, contínua afirmação de pertença ao lugar e reivindicação de reconhecimento do indivíduo como legítimo ocupante de papéis sociais específicos (homem, pai de família, provedor). O permanente refazimento da identidade e da memória social toma como coordenada a persistência do vínculo - mesmo que parcial - com a pesca.

O apreço pelo sabor do peixe - e a preferência por ele em relação a outras carnes - também constitui fator predisponente à continuidade da pesca, especialmente devido aos preços praticados no comércio local, que tornam mais vantajosa a obtenção do pescado na natureza. Algo similar, aliás, ocorre com a mariscagem: o caranguejo, o siri e o sarnambi permanecem, apesar da crescente oferta de diferentes tipos de alimentos (inclusive industrializados) em Marudá, como opções preferenciais de consumo entre os moradores permanentes do local.

Concorrem, portanto, distintos fatores aptos a justificar a permanência das práticas de extrativismo animal - e particularmente da pesca - em Marudá. E, embora os aspectos simbólicos e gustatórios surjam, na presente investigação, como relevantes hipóteses, pouco exploradas em pesquisas anteriores, deve-se ressaltar que a pesca continua a figurar como efetiva fonte de renda monetária e de segurança nutricional para significativa parcela das famílias residentes nos bairros Sossego e Alegre, ao menos sazonalmente.

\section{Ofícios de costureira, artesã, erveira e marisqueira}

Ao passo em que a pesca - mas não a mariscagem - continua a ser indicada como domínio de atuação fundamentalmente masculino em Marudá, outro conjunto de ocupações é referido como domínio de especialização feminina. Trata-se de ocupações desenvolvidas no âmbito do espaço doméstico e outros espaços de mais restrita visibilidade, embora incluam, em alguns casos, atividades ligadas à exploração de recursos ambientais. São elas: costura de roupas, bordados, crochês, artesanatos diversos, cultivo de plantas medicinais e frutíferas em quintais, coleta de plantas medicinais na natureza, produção de remédios caseiros e criação de aves, em particular galinhas. Conformam-se, assim, os ofícios de costureira, artesã e erveira, via de regra flexionados em referência ao sexo feminino. As competências nos referidos ofícios figuram, nas trajetórias de vida de moradoras mais idosas, como marcos da ocupação de particulares papéis sociais, como o de esposa. 
A costura, o artesanato e a manipulação de fitoterápicos se apresentam como tarefas entrecruzadas no cotidiano das mulheres e sua execução é frequentemente referida por meio da contraposição ao "trabalho duro da pesca", como "trabalho manso", "serviço de mulher". Tal oposição se sustenta no superior grau de esforço que os homens alegam empregar nos empreendimentos de captura em alto-mar, perseguindo cardumes em fuga. Os ofícios das mulheres, ao contrário, estariam ligados não à captura, mas à coleta, supostamente amena, de plantas, sementes e outros alvos imóveis ou com mobilidade limitada. Por isso, inclusive, a mariscagem (Figura 8) estaria mais próxima à esfera de atuação feminina que à masculina.

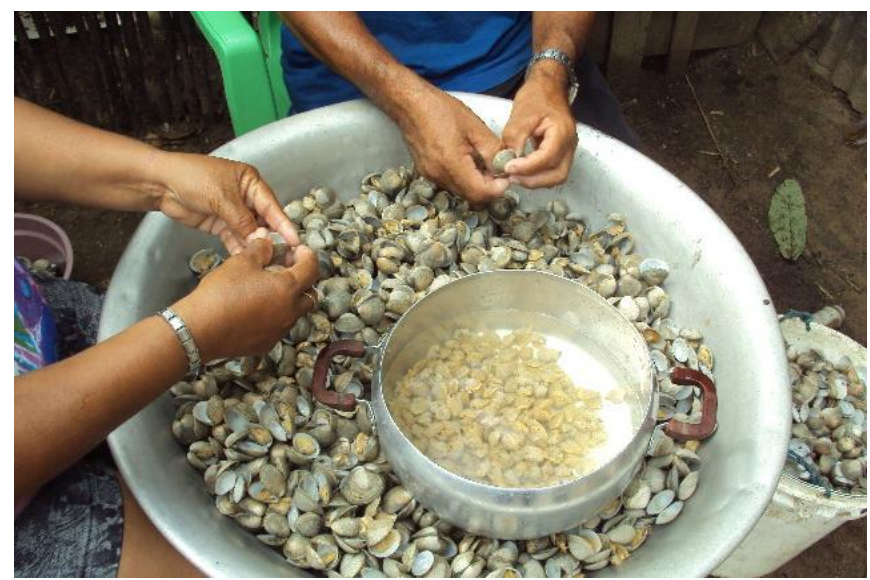

Figura 8: Mulher retira massa do molusco sarnambi (várias espécies) com amigo. Fonte: pesquisa de campo (2017).

Figure 8: Woman extracts viscera of sarnambi mollusk (various species) with friend. Source: field research (2017).

Reside, porém, na citada oposição, um par de contradições. Em primeiro lugar, a pesca de curral, apesar de herdar a estima formulada em torno da pesca em alto-mar, emprega armadilhas fixas e se assemelha a uma atividade de coleta. Em segundo lugar, parcela significativa das atividades de extrativismo vegetal e de beneficiamento desses recursos, especificamente no trato com madeiras, é de alçada masculina. Assim, embora muitos homens ainda se apresentem e sejam localmente apontados como pescadores, e apesar da raridade de menções ao ofício de artesão, ficam geralmente sob seu encargo as atividades de extração de madeira de restingas e manguezais para obras domésticas, para projetos de marcenaria, bem como para construção de currais, de pequenos barcos, e de artefatos de pesca. Do mesmo modo, cabe aos homens a transformação da madeira em carvão vegetal.

No âmbito das atividades de coleta, ocorre, com frequência, busca de recursos úteis em outras localidades de Marapanim, onde eventualmente se verifica maior abundância de determinados bens ambientais visados. $\mathrm{Na}$ praia da vila do Crispim, por exemplo, é comum que se busquem crustáceos, moluscos e pescado. Nas margens alagáveis dos rios Marapanim e Cajutuba e tributários, é comum que se busquem sementes de andiroba (Carapa guianensis Aublet), cujo óleo, extraído por técnicas artesanais, é útil como repelente de insetos e anti-inflamatório. Os deslocamentos 
temporários dos marudaenses em busca de recursos para além de sua própria localidade são favorecidos pela existência de laços de parentesco entre moradores de diferentes regiões do município. Essas incursões oportunizam a realização e retribuição de visitas entre parentes, que fornecem pousada ao viajante e certificam sua índole para os demais moradores da localidade adentrada.

Interessante, por fim, pontuar que a mariscagem, ofício dissociado da pesca no domínio mais amplo do extrativismo animal, se apresenta por meio de alternativas configurações nas distintas épocas do ano. $\mathrm{Na}$ baixa temporada, visa principalmente à satisfação alimentar dos moradores permanentes, enquanto no veraneio visa à demanda dos visitantes. Em consequência, famílias bem integradas a redes de prestação de serviços a veranistas intensificam a mariscagem na baixa temporada, quando os veranistas estão ausentes, para suprir sua subsistência; e famílias fracamente articuladas à prestação de serviços intensificam a mariscagem no veraneio, para vender o produto das coletas nas praias e de algum modo tirar vantagem da sazonal presença dos veranistas em Marudá.

\section{Discussão}

É notório que, no cotidiano dos moradores permanentes do Sossego e Alegre, articulam-se práticas de trabalho com maior profundidade temporal e práticas datadas de período mais recente, cada qual se constituindo a partir de circunstâncias particulares. Os estilos de vida atualizados por esses moradores geralmente portam aparência híbrida, conexa à sazonalidade de seu intercurso com os moradores temporários e demais veranistas.

O simples registro da particular configuração de relações sociais articuladas na localidade de Marudá, em si, representa contribuição ao estudo do nexo entre turismo e mudança social. Restava, pois, até então, insuficientemente descrita a sazonalidade específica associada ao fenômeno do turismo de segunda residência e a ambivalência do modo de organização do cotidiano nesses polos de visitação, sobretudo no litoral amazônico. Conforme Neves (1995), o estudo da mudança deve se pautar pela demonstração do processo de rearticulação de relações entre atores sociais ao longo do tempo, e o trabalho ora apresentado constitui precisamente um esforço demonstrativo do modo como tais relações têm sido estruturadas em um singular contexto espaço-temporal na costa atlântica da Amazônia.

Além de corroborar uma determinada corrente interpretativa pavimentada, dentre outros, por Adrião (2006), Assis $(2001$; 2003) e Martins e Molina (2008) - com dados empíricos especificamente produzidos em torno da categoria "cotidiano", o texto se volta, nesta seção, à categoria "interação". Enquanto o registro do cotidiano permite desvelar o hibridismo dos estilos de vida atualizados pelos marudaenses, é a análise sob o prisma da interação que possibilita a propositura de interpretações menos deterministas ou fatalistas do processo de mudança no polo balnear.

Promove-se, desta feita, a título de discussão, o exercício comparativo de analisar o cotidiano ambivalente dos marudaenses a partir de dois conjuntos teóricos divergentes: um que toma o hibridismo como fator 
organizativo do cotidiano de Marudá, tal qual um fato social (cf. DURKHEIM, 2001, para conceituação do termo), externo e superior às vontades particulares dos marudaenses; e um que toma o hibridismo do cotidiano como expressão dos jogos de interação entre atores sociais específicos, sobretudo marudaenses e turistas (inclusos os moradores sazonais).

Busca-se, assim, evidenciar que a atenção ou, por outro lado, a desatenção à ideia de interatividade entre atores sociais conduz a interpretações díspares dos dados correlatos ao hibridismo do cotidiano em polos de turismo de segunda residência. Por isso, o contínuo enfoque em torno da ideia de interação poderá ser o cuidado necessário para evitar que concepções desgastadas - p. ex., aculturação, assimilação cultural ressurjam como matrizes interpretativas hegemônicas para a compreensão do nexo entre turismo e mudança social em contextos de pesquisa marcados por imagens ambíguas de mudanças e permanências.

Por clareza conceitual, indica-se que a concepção de interação aqui adotada decorre de Goffman (1967) e engloba as subcategorias de interações focadas e interações não focadas. Interações focadas são os efetivos encontros entre atores sociais, abarcando pessoas em situações comunicativas, que se alternam na conversação, como familiares, amigos e vizinhos (inclusive, no caso de Marudá, os vizinhos temporários). Interações não focadas são aquelas mantidas com os demais indivíduos presentes na cena do encontro, com os quais não se colabora para formar um centro de interesse comunicativo (no caso de Marudá, a maior parte dos contatos dos moradores permanentes com os visitantes ocasionais).

Considerando o recorte proposto, há, de uma banda, a vertente analítica que se atém estritamente ao fato do hibridismo. Evitando adentrar as minúcias das interações sociais, trabalhos que adotam tal perspectiva de análise tendem a conceber a coexistência de concorrentes universos de práticas sociais em localidades turísticas como estágio intermediário de um mais amplo processo de desarticulação da vida haliêutica e triunfo da vida balnear. Menos por inaptidão científica de autores individuais que por força de uma longeva tendência interpretativa, ainda em voga, tal visão pode ser identificada, por exemplo, nos textos de Furtado et al. (2006) e CoelhoFerreira (2009), produzidos a partir de experiências de trabalho de campo em Marudá.

Segundo essa vertente de análise, estaria em marcha, em Marudá, um inconcluso processo de difusão de particulares estilos de vida e formas de engajamento ao âmbito do trabalho, desde a esfera urbana de Belém até a localidade costeira, com a consequente perda da cultura local. Este viés interpretativo se coaduna com a "escola difusionista" da Antropologia e, embora tenha sofrido críticas neste campo disciplinar (CASTRO, 2016, p. 25), ocasionalmente ressurge como chave explicativa em trabalhos de cunho interdisciplinar tangencialmente referidos à temática social (PRADO; MURRIETA, 2015, p. 142-143). Adotar esta perspectiva provê uma gama de possibilidades de compreensão dos fenômenos enfocados: desde o recurso às noções de aculturação da sociedade local e homogeneização cultural à sociedade abrangente (p. ex., SAYNES-VÁSQUEZ et al., 2013), até a ideia 
de que a eventual adoção de traços culturais exógenos ocorre em conformidade com particulares "configurações de cultura" do grupo social receptor, como reinterpretação e não simples incorporação desses traços (BASTIDE, 1956; BENEDICT, 1932).

Desse modo, também seria possível atribuir, à articulação entre os distintos conjuntos enfocados de práticas de trabalho, o caráter de evidência da passagem de uma a outra ordem de vivência do tempo. Pois, por um lado, a perspectiva cíclica de vivência do tempo prescreve a recorrência de estágios, em periódica substituição recíproca; e, por outro, a perspectiva linear sugere que o tempo e a história podem ser imaginados como uma flecha, avançando irreversivelmente por sucessivas etapas de mudança da sociedade (SZTOMPKA, 1998). Assim, se as sociedades locais, de pequena escala, são retratadas como microcosmos regidos pela sazonalidade de ciclos naturais, reproduzindo uma ordem tradicional - mesmo que com inovações de saberes e técnicas (TOLEDO; BARRERA-BASSOLS, 2009) -, a urbana é descrita em termos de evolução, progresso histórico, modernidade (NEVES, 1995). E a intensificação do intercurso da população residente em Marudá com os veranistas significaria, enfim, a ruptura da vivência do tempo baseada nos ciclos naturais e a transição para o estágio de evolução linear, ou a superação da sociedade tradicional em favor da sociedade moderna.

Ainda que Thompson (1998) tenha legado relevante contribuição com o estudo de um caso historicamente significativo de reconfiguração dos modos de experimentar a passagem do tempo - a saber, aquela ambientada na Revolução Industrial inglesa do século XVIII -, é temerário pretender que suas conclusões, ancoradas em um contexto social específico, possam ser tomadas como modelo geral da mudança, aplicável a qualquer situação empírica.

Tanto a noção de difusão de traços culturais em sentido único quanto a de transição a novas formas de vivenciar a passagem do tempo inspiram, enfim, imagens etnocêntricas, atribuindo à sociedade urbana a condição de meta a ser perseguida pelas demais sociedades, sob esta ótica vistas como atrasadas, subdesenvolvidas (cf. STAVENHAGEN, 1985). Em consequência, a mudança seria tida como produto da ação de agentes externos, à revelia dos atores locais, suas vontades e capacidades de articulação. $O$ ingresso de certos atores, como veranistas e planejadores, oportunizaria a difusão de relações, sociabilidades e aspirações particulares da sociedade abrangente, levando à substituição dos estilos de vida atualizados no âmbito da sociedade local.

Por conseguinte, a relação entre os dois conjuntos descritos de práticas de trabalho dos interlocutores não seria de articulação, mas de substituição, de progressiva transição de uma a outra lógica de organização da vida econômica e do cotidiano. E a ascensão do turismo balnear, por sua vez, embora não figurando como causa primeira do declínio da atividade pesqueira, teria que ser concebida como processo motriz da desarticulação dos remanescentes traços de atualização da pesca e de valorização de seus aspectos simbólicos. 
Tal interpretação, porém, se opõe sobremaneira às observações produzidas no trabalho de campo, que atestam a vitalidade de práticas tais quais a pesca, a mariscagem e o extrativismo vegetal no cotidiano dos moradores de Marudá. E embora as citadas práticas não estejam mais disseminadas a ponto de autorizar seu uso na caracterização da totalidade da vida econômica do distrito - como a literatura registra ter sido uma vez possível -, seu sazonal fortalecimento indica existir uma lacuna temporal que até então a vida balnear não ocupou. Esse quadro de maior simetria entre mudanças e permanências possivelmente decorre das especificidades do turismo de segunda residência em relação àquele de plena projeção comercial. Em tal contexto, os marudaenses lidam com um processo de mudança menos agressivo que aquele descrito por Caroso e Rodrigues (1998), Oliveira (2005), Netto e Miraldi (2017) e Gascón e Milano (2018), e que não se espraia por todo o ciclo anual, deixando ainda significativas parcelas de tempo tão vazias de vida balnear quanto demandantes de alternativas à satisfação das necessidades dos residentes.

Para o caso analisado, enfim, o primeiro conjunto teórico enfocado não se sustenta como alternativa viável de interpretação. De outra banda, passa-se a levar em consideração a categoria "interação", valorizando-se o estudo do intercurso de atores sociais diversos nas cenas de encontro, para as quais convergem concorrentes vontades, recursos e estratégias de articulação.

Coloca-se, então, como alternativa analítica, a perspectiva designada como "teoria da ação" (FELDMAN-BIANCO, 1987), que, desde Firth (1974), se diferencia por conceber os atores sociais não como robôs, obedecendo mecanicamente a um programa estrutural pré-definido, mas como agentes, capazes de se mover taticamente nos interstícios da estrutura social, articulando estratégias de organização e manipulando diversamente os conjuntos de recursos de que dispõem. Desse modo, no caso em foco, nem os moradores permanentes de Marudá - ainda que efetivamente limitados por condições estruturais particulares - poderiam ser concebidos como meros espectadores dos processos de mudança ou receptores passivos de traços exógenos, nem a própria mudança poderia ser vista como emanando integralmente a partir do exterior, promovida pelos agentes oriundos da formação social abrangente, e seguindo um roteiro predeterminado.

O viés difusionista antes citado, então, encontraria utilidade, no máximo, por estimular a reflexão sobre os efeitos potencialmente decorrentes da intensificação do intercurso entre moradores locais e veranistas - questão que se complexifica se considerada a diferenciação interna correlata a cada uma dessas duas categorias de atores. Há, afinal, recorrente confronto entre distintos estilos de vida, formas de sociabilidade e padrões de consumo, circunstanciado mediante as mais diversas situações de encontros durante o veraneio, das quais dificilmente os indivíduos envolvidos escapam sem que ocorra uma mínima tentativa de tipificação recíproca (cf. BERGER; LUCKMANN, 1966; GOFFMAN, 1967). O que, porém, transita e flui entre os indivíduos não são traços culturais em si, como pretendiam os difusionistas, mas apenas significações construídas em torno de questões ou episódios singulares, destinatários de atenções mútuas entre 
os atores em interação.

Os serviços contratados pelos moradores sazonais e prestados pelos permanentes, por exemplo, figuram como relações em torno das quais se aglutinam atenções e se organizam disputas entre concorrentes referenciais valorativos e atributivos de significações, correlatos aos distintos universos sociais em contato. As significações aí triunfantes não são meramente doadas e recebidas, mas negociadas, mormente devido ao caráter informal das contratações. Por isso, no que concerne a este exemplo, podem-se entender tais contratações não como simples assimilação de demandas dos moradores urbanos pelos moradores da localidade costeira - às custas de suas ocupações mais antigas e costumeiras -, mas como ampliação do leque de recursos disponíveis aos atores locais no âmbito da definição de suas estratégias de reprodução social. O que poderia ser visto como implante ou degradação de uma cultura ou de um modo de vida pode, em vez disso, ser visto como articulação de emergentes relações sociais, que se inscrevem no cotidiano dos moradores permanentes de maneira negociada e em conformidade com seus respectivos universos sociais de significações.

Por sua vez, as noções de alternativas modalidades de experimentar a passagem do tempo, se consideradas à luz da teoria da ação, aportam renovadas contribuições à compreensão do nexo entre mudanças e continuidades sociais. Não mais são vistas como modelos reciprocamente excludentes, nem como metáforas rígidas de uma suposta evolução social. A mudança, afinal, não deve ser concebida como erupção de algo inteiramente novo, em tudo contraposto às circunstâncias precedentes. Deve ser entendida como contextual processo de reconfiguração, que encontra, nas circunstâncias antecedentes, suas condições de constituição. Não existe, portanto, mudança absoluta - mesmo que seu ritmo seja intenso e ela afete a própria estrutura social -, nem absoluta permanência - ainda quando não há nenhum relevante fator promotor de mudanças. Da mesma maneira, a vivência do tempo não está aprisionada a uma ou outra visão extrema - a flecha que sempre avança ou o eterno recomeço -, podendo combinar ambas as lógicas. O proveito dessas imagens decorre, assim, de seu emprego como instrumentos descritivos de processos de mudança, em seus aspectos lineares e circulares (SZTOMPKA, 1998).

A sobrevalorização da mudança ou da permanência, da linearidade ou da circularidade, cria imagens distorcidas, que, exagerando um polo ou o outro, dificultam o reconhecimento da especificidade das posições assumidas pelos atores sociais abarcados pelo processo. Um e outro polo, afinal, estão separados por uma notável distância, que reflete a diversidade de formas intermediárias como as distintas situações de mudança podem ser descritas. No caso de Marudá, tais formas intermediárias correspondem às alternativas maneiras de organização do cotidiano dos moradores permanentes, cada qual abrangendo, em diferentes proporções, elementos de mudanças e continuidades, de linearidade e circularidade.

A própria sazonalidade do turismo balnear favorece a percepção desse binômio. Mas, ainda assim, tal padrão não determina uma configuração única de estruturação do cotidiano em Marudá. Sendo, os 
moradores, titulares de recursos próprios - saberes ligados a ofícios, laços de consanguinidade ou solidariedade, tempo, força de trabalho -, tornam-se capazes de gerir, ao menos parcialmente, sua articulação aos demais atores partícipes do processo de mudança. A mudança é, assim, negociada e diversamente integrada ao cotidiano dos moradores. A diversidade de formas de organização social que ali se observa, contrastando diferentes padrões de linearidade e circularidade, reflete, então, não apenas a sazonalidade do turismo balnear, mas também distintos níveis de ousadia e hesitação com que os moradores locais investem no intercurso com os moradores sazonais e demais veranistas. Tal compreensão, contudo, apenas é possível quando valorizada a investigação da dimensão interativa dos encontros entre moradores e visitantes, o que desvela o caráter pactuado do cotidiano na localidade balnear.

\section{Considerações finais}

A investigação conduzida em Marudá permite constatar a existência de um duplo engajamento laboral dos moradores permanentes da localidade. Há, por um lado, o universo ocupacional ligado a atividades portadoras de maior profundidade temporal, como a pesca, a mariscagem, 0 extrativismo vegetal, o artesanato e a fitoterapia popular. Há, por outro lado, o universo ocupacional constituído em torno do polo balnear e das práticas de visitação turística encenadas na localidade, reconhecido por uma série de ofícios emergentes.

Os dois universos de trabalho representam distintos conjuntos de práticas sociais e socioambientais, uma vez que comportam relações entre agentes específicos e formas particulares de utilização dos recursos naturais. E apesar de inspirarem, em uma superficial análise, a ideia de oposição, apresentam-se de modo integrado e articulado no âmbito do cotidiano marudaense.

A articulação entre esses dois universos no cotidiano marudaense promove não uma segmentação social, mas uma segmentação temporal, sazonalmente determinada. Não se tem verificado, pois, a especialização profissional dos marudaenses em ofícios particulares, mas o engajamento em cumulativos ofícios. E os padrões de engajamento são temporalmente variáveis, exibindo configurações específicas no curso de um ciclo anual. Durante o veraneio, investe-se no intercurso com os turistas; os marudaenses se dedicam aos ofícios que visam ao atendimento das demandas do polo balnear. Durante o longo intervalo entre dois veraneios consecutivos, investe-se nos ofícios ligados à exploração dos recursos naturais, em adição às ocasionais oportunidades de exercício dos ofícios correlatos ao polo balnear. As práticas de visitação turística objetivadas em Marudá, afinal, correspondem ao modelo de turismo de segunda residência, fortemente marcado pela sazonalidade das atividades metropolitanas e suas folgas programadas. Desse modo, o sazonal influxo de visitantes que constitui o período de veraneio figura como importante fator da periódica reestruturação do cotidiano de Marudá, estimulando a reorganização dos engajamentos laborais da população permanente da localidade. 
Assim, os conjuntos de práticas e as relações sociais subjacentes a cada um poderiam ser vistos como dois diferentes universos de recursos, a que os moradores permanentes se vinculam diversamente nas distintas temporadas conformadoras do ciclo anual. Em consequência, as relações entre esses dois universos de recursos seriam relações de concorrência, alternância e complementaridade: de concorrência, pois os dois universos são diversamente valorizados (priorizados/preteridos) no curso do tempo, reciprocamente avaliados quanto à vantagem econômica que cada um pode prover em circunstâncias particulares; de alternância, pois o exercício das práticas correlatas a cada universo varia ao longo do ano, em padrões de recíproca intensificação/supressão; de complementaridade, pois a conciliação entre os dois alternativos universos, em esforço tático e coerente, representa o vetor estruturante das estratégias de reprodução social da população fixa de Marudá.

O turismo, enfim, tanto como cenário de relações sociais específicas, quanto como ramo de atividade econômica, aglutina idealizações e acusações em seu entorno, e a presente investigação pretendeu contribuir para o esforço de inventariar a diversidade de configurações correlatas a essa categoria de ação humana. Buscou-se evidenciar, sobretudo, a partir de uma situação empírica particular, que as práticas de visitação turística, em determinados contextos, não representam fator de desagregação cultural. Tais práticas, ao contrário, podem favorecer que as populações residentes nas localidades receptoras assumam papel ativo no processo de mudança ali iniciado, beneficiando-se da oportunidade de interação com os diferentes segmentos sociais reunidos sob a qualificação de turistas.

\section{Referências}

ADRIÃO, D. Pescadores de sonhos: um olhar sobre as mudanças nas relações de trabalho e na organização social entre as famílias dos pescadores diante do veraneio e do turismo balnear em Salinópolis, Pará. Boletim do Museu Paraense Emílio Goeldi. Ciências Humanas, v.1, n.2, p.11-21, 2006.

ASSIS, L.F. A difusão do turismo de segunda residência nas paisagens da ilha de Itamaracá - PE. Boletim goiano de Geografia, v.21, n.2, p.103-135, 2001.

ASSIS, L.F. Turismo de segunda residência: a expressão espacial do fenômeno e as possibilidades de análise geográfica. Revista Território, ano 7, n.11/12/13, p.107-122, 2003.

BARBOSA, H.D.A.; CAMPOS, R.I.R. Experiências de turismo em unidades de conservação em áreas haliêuticas no Estado do Pará/Amazônia. Pasos: revista de turismo y patrimonio cultural, v.15, n.4, p.823-839, 2017.

BARRETTO, M. O imprescindível aporte das ciências sociais para 0 planejamento e a compreensão do turismo. Horizontes Antropológicos, v.9, n.20, p.15-29, 2003.

BASTIDE, R. La causalité externe et la causalité interne dans l'explication sociologique. Cahiers internationaux de sociologie, n.21, p.77-99, 1956. 
BENEDICT, R. Configurations of culture in North América. American Anthropologist, v.34, n.1, p.1-27, 1932.

BERGER, P. L.; LUCKMANN, T. Society as objective reality. In: BERGER, P. L.; LUCKMANN, T. The social construction of reality: a treatise in the Sociology of knowledge. Nova lorque: Penguin Books, p. 63-146, 1966.

BORCEM, E.R.; FURTADO JÚNIOR, I.; ALMEIDA, I.C.; PALHETA, M.K.S.; PINTO, I.A. A atividade pesqueira no município de Marapanim-Pará, Brasil. Revista de ciências agrárias, v.54, n.3, p.189-201, 2011.

CAMPOS, R.I.R.; NASCIMENTO, M.D.S.; MENDONÇA, S.C. Reserva Extrativista Marinha Mestre Lucindo (PA): processo de criação e perspectivas para o turismo. Revista brasileira de ecoturismo, v.10, n.2, p.300-327, 2017.

CAROSO, C; RODRIGUES, N. Nativos, veranistas e turistas: identidades, mudança e deslocamento sociocultural no litoral norte da Bahia. Turismo em análise, v.9, n.1, p.61-75, 1998.

CASTRO, C. A escola difusionista. In: CASTRO, C. (Org.). Textos básicos de Antropologia. Rio de Janeiro: Zahar, p.25, 2016.

COELHO-FERREIRA, M. Medicinal Knowledge and plant utilization in an Amazonian coastal community of Marudá, Pará State (Brazil). Journal of Ethnopharmacology, n.126, p.159-175, 2009.

CUCHE, D. O estudo das relações entre as culturas e a renovação do conceito de cultura. In: CUCHE, D. A noção de cultura nas ciências sociais. Bauru: EDUSC, p.109-142, 1999.

CUNHA, M.C. Relações e dissensões entre saberes tradicionais e saber científico. Revista USP, n.75, p.76-84, 2007.

DURKHEIM, E. As regras do método sociológico. 8. Ed. Lisboa: Editorial Presença, 2001.

FELDMAN-BIANCO, B. Introdução. In: FELDMAN-BIANCO, B. (Org.). Antropologia das sociedades contemporâneas. São Paulo: Global Universitária, p.7-45, 1987.

FIRTH, R. O significado da antropologia social. In: FIRTH, R. Elementos de organização social. Rio de Janeiro: Zahar, p.44-57, 1974.

FURTADO, L.G. Aspectos históricos e econômicos de Marapanim nordeste paraense. Boletim do Museu Paraense Emílio Goeldi. Antropologia, n.67, p.1-32, 1978.

FURTADO, L.G.; NASCIMENTO, I.H.; SANTANA, G.; MANESCHY, M.C. Formas de utilização de manguezais no litoral do estado do Pará: casos de Marapanim e São Caetano de Odivelas. Amazônia: Ciência \& Desenvolvimento, v.1, n.2, p.113-127, 2006.

GASCÓN, J.; MILANO, C. Tourism, real estate development and depeasantisation in Latin America. Revista Europea de Estudios Latinoamericanos y del Caribe, n.105, p.21-38, 2018.

GOFFMAN, E. Interaction ritual: essays on face-to-face behavior. Nova lorque: Doubleday Anchor, 1967. 
LOPES JÚNIOR, W.M. Turismo de segunda residência na orla do distrito de São Tomé em Campos dos Goytacazes, Rio de Janeiro. Geografia Ensino \& Pesquisa, v.19, n.1, p.27-38, 2015.

MARTINS, J.S.; MOLINA, S.M.G. Turismo e a emergência de novas territorialidades: o caso de Itaúna-ES. Iluminuras, v.9, n.22, 2008.

NASCIMENTO, I. Tempo de fartura e tempo de famitura no litoral do Pará. Boletim do Museu Paraense Emílio Goeldi. Ciências Humanas, v.1, n.2, p.23-33, 2006.

NETTO, M.N.; MIRALDI, J.C. Turismo de luxo: a produção do destino e a denegação do social. Repocs, v.14, n.28, p.191-218, 2017.

NEVES, D.P. Mudança social: exorcizando fantasmas. Antropolítica, v.1, n.1, p.49-73, 1995.

NEVES, D.P. Antropologia: alteridade e dispersões temáticas. In: VARGAS, J.T.; FARIA, D.S. (Orgs.). Textos interdisciplinares: um olhar integrado sobre a Amazônia, o Brasil e o conhecimento. São Paulo/Santarém: Humanitas, p.117-160, 2017.

OLIVEIRA, A.C. Turismo em áreas "menos desenvolvidas": caracterização, desenvolvimento e planejamento turístico da Vila de Trindade, município de Paraty/Rio de Janeiro - Brasil. Pasos: revista de turismo y patrimonio cultural, v.3, n.1, p.149-169, 2005.

POTIGUAR JÚNIOR, P.L.T. Uma etnografia da migração interna de pescadores no nordeste paraense. In: Encontro da Associação Nacional de Pós-Graduação e Pesquisa em Planejamento Urbano e Regional, 9. Anais... Rio de Janeiro: Anpur, p.1354-1364, 2001.

PRADO, R.M. As espécies exóticas somos nós: reflexão a propósito do ecoturismo na Ilha Grande. Horizontes Antropológicos, v.9, n.20, p.205224, 2003.

PRADO, H.M.; MURRIETA, R.S.S. A etnoecologia em perspectiva: origens, interfaces e correntes atuais de um campo em ascensão. Ambiente \& Sociedade, v.18, n.4, p.139-160, 2015.

SANTOS, R.J.; BARRETTO, M. Aculturação, impactos culturais, processos de hibridação: uma revisão conceitual dos estudos antropológicos do turismo. Turismo em Análise, v.17, n.2, p.244-261, 2006.

SAYNES-VÁSQUEZ, A; CABALLERO, J.; MEAVE, J.A.; CHIANG, F. Cultural change and loss of ethnoecological knowledge among the Isthmus Zapotecs of Mexico. Journal of Ethnobiology and Ethnomedicine, v.9, p.40, 2013.

SILVA, C.G.; FLOR. A.S.O.; MONTEIRO, M.; BARBOSA, W.L.R. Desenvolvimento local sustentável como liberdade: planejamento estratégico de organização comunitária. Universidade e meio ambiente, v.1, n.1, p.116, 2016.

STAVENHAGEN, R. Etnodesenvolvimento: uma dimensão ignorada no pensamento desenvolvimentista. Anuário Antropológico 1984. Rio de Janeiro: Tempo Brasileiro, 1985. p.11-44. 
SZTOMPKA, P. Conceitos fundamentais no estudo da mudança; As vicissitudes da ideia de progresso. In: SZTOMPKA, P. A sociologia da mudança social. Rio de Janeiro: Civilização brasileira, p. 23-82, 1998.

THOMPSON, E.P. Tempo, disciplina de trabalho e capitalismo industrial. In: THOMPSON, E.P. Costumes em comum: estudos sobre a cultura popular tradicional. São Paulo: Companhia das Letras, p.267-304, 1998.

TOLEDO, V.M.; BARRERA-BASSOLS, N. A etnoecologia: uma ciência pósnormal que estuda as sabedorias tradicionais. Desenvolvimento e Meio Ambiente, v.20, p.31-45, 2009.

TURNER, V. Passages, margins, and poverty: religious symbols of communitas. In: Dramas, fields and metaphors: symbolic action in human society. Ithaca: Cornell University Press, 1975.

\section{Natureza do trabalho e financiamento}

Este artigo decorre da tese de doutorado do autor, apresentada sob o título de "Turismo, trabalho e uso de recursos naturais no litoral paraense: a construção da noção de mudança na localidade costeira de Marudá, Amazônia Atlântica", ao Programa de Pós-Graduação Sociedade, Natureza e Desenvolvimento - PPGSND, da Universidade Federal do Oeste do Pará - UFOPA.

O presente trabalho foi realizado com apoio da Coordenação de Aperfeiçoamento de Pessoal de Nível Superior - Brasil (CAPES) - Código de Financiamento 001.

\section{Agradecimentos}

Agradeço à CAPES, pela concessão de bolsa de estudos de doutorado. Agradeço à professora Luciana Gonçalves de Carvalho e ao professor Flávio Bezerra Barros, respectivamente, orientadora e coorientador da tese. Agradeço, por fim, à professora Delma Pessanha Neves, pelo incentivo de longa data e pelas pertinentes colocações a respeito do estudo da mudança social na oportunidade da defesa pública da tese, em 20 de fevereiro de 2019, na cidade de Santarém-PA.

Diego Corrêa Furtado: Universidade Federal do Oeste do Pará, Santarém, PA, Brasil.

E-mail: dkhasinau@gmail.com

Link para o currículo Lattes: http://lattes.cnpq.br/6665682528798800

Data de submissão: 17 de maio de 2019

Data de recebimento de correções: 22 de junho de 2019

Data do aceite: 22 de junho de 2019

Avaliado anonimamente 
